\title{
Comparison of receptor models for source apportionment of the PM10
}

\section{in Zaragoza (Spain)}

\author{
M.S. Callén*, M.T. de la Cruz, J.M. López, M.V. Navarro, A.M. Mastral \\ Instituto de Carboquímica (CSIC), Miguel Luesma Castán, 4, 50018 Zaragoza (Spain) \\ ${ }^{*}$ Corresponding author. Phone number: +34 976 733977; Fax number: +34 976733318 \\ e-mail: $\underline{\text { marisol@icb.csic.es }}$
}

\section{Abstract}

Receptor models are useful to understand the chemical and physical characteristics of air pollutants by identifying their sources and by estimating contributions of each source to receptor concentrations. In this work, three receptor models based on principal component analysis with absolute principal component scores (PCA-APCS), Unmix and Positive Matrix Factorization (PMF) were applied to study for the first time the apportionment of the airborne particulate matter less or equal than $10 \mu \mathrm{m}$ (PM10) in Zaragoza, Spain, during one year sampling campaign (2003-2004). The PM10 samples were characterized regarding their concentrations in inorganic components: trace elements and ions and also organic components: polycyclic aromatic hydrocarbons (PAH) not only in the solid phase but also in the gas phase.

A comparison of the three receptor models was carried out in order to do a more robust characterization of the PM10. The three models predicted that the major sources of PM10 in Zaragoza were related to natural sources $(60 \%, 75 \%$ and $47 \%$ respectively for PCA-APCS, Unmix and PMF) although anthropogenic sources also contributed to PM10 (28\%, 25\% and 39\%). With regard to the anthropogenic sources, while PCA and PMF allowed high discrimination in the sources identification associated with different combustion sources such as traffic and industry, fossil fuel, biomass and fuel oil combustion, heavy traffic and evaporative emissions, the Unmix model only allowed 
the identification of industry and traffic emissions, evaporative emissions and heavy duty vehicles. The three models provided good correlations between the experimental and modelled PM10 concentrations with major precision and the closest agreement between the PMF and PCA models.

Keywords: PM10; Receptor modelling; PCA-APCS; Unmix; PMF

\section{Introduction}

Air pollution constitutes a widespread problem affecting millions exposed to high levels of air pollution that exceed one or more ambient limit values. One of these air pollutants is the particulate matter (PM), which is composed of a broad class of chemically and physically diverse substances. PM can be very variable in size, chemical composition, formation mechanism and origin. In addition, its concentration, which is variable across space and time, is also a function of sources, atmospheric reactions and meteorological conditions. Health effects associated with PM are linked to respiratory, cardiovascular health problems and premature mortality.

Receptor modelling is the application of multivariate statistical methods addressed to the identification and quantitative apportionment of air pollutants to their sources (Hopke et al., 2006). During the last years, these models have been accepted for developing effective and efficient air quality management plans. Different models including principal component analysis/absolute principal component scores (PCAAPCS) (Song et al., 2006a; García et al., 2006), edge analysis (Unmix (Song et al., 2006a; Olson and Norris, 2008), chemical mass balance (CMB) (Chow and Watson 2002; Cooper et al. 1984) and positive matrix factorization (PMF) (Paatero, 1997; Paatero, 1999; Gildemeister et al., 2007) have been applied to identify and to establish the sources contribution to observed ambient concentrations. While most of the studies have been focused to study the apportionment of the PM as a function of the inorganic 
components (Hopke, 2003; Song et al., 2006a,b), only few references have been found with regard to the organic component of the PM, in particular PAH (Ke et al., 2008). In addition, there are not a lot of references based on the application of several receptor models for the apportionment of particulate matter in Spain (Viana et al., 2008).

In this paper, the Zaragoza PM10 has been chemically characterized not only from the inorganic point of view (trace elements and ions) but also from the organic point of view (PAH). Once characterized, three different models, PCA/APCS, Unmix and PMF, have been applied in order to identify and quantify the PM10 sources in Zaragoza. Special attention was paid to the models comparison in order to determine which models were more adequate for the apportionment.

Briefly, PCA is a tool for analyzing structure in multivariate data sets. It starts with a large number of correlated variables and seeks to identify a smaller number of independent factors that can be used to explain the variance in the data. The derived variables are linear combinations of original variables and sources are estimated quantitatively and at daily scale by using the APCS method described by Thurston and Spengler (1985), which uses the obtained scores for each specie and day.

Unmix is one of the receptor models that the United States Environmental Protection Agency's Office of Research and Development (ORD) has developed. UNMIX uses the singular value decomposition (SVD) method to estimate the source number by reducing the dimensionality of data (Henry, 2003).

PMF is a factor analytic technique that uses non negativity constraints and allows nonorthogonal factors (Paatero, 1997). This model was developed by Paatero (Paatero and Tapper, 1993) and implemented by the EPA. The structure of PMF permits maximum use of available data and better treatment of missing and below detection limit values. 
Uncertainty also plays an important role in this model because it reflects the quality and reliability of each data point.

\section{Materials and methods}

\subsection{Study area and sampling description}

The study was performed in the city of Zaragoza, located in the North-East of Spain, by using a Graseby Andersen high-volume air sampler provided with a PM10 cut off inlet to collect particulate phase in a Teflon-coated, fibre-glass filter $(0.6 \mu \mathrm{m}$ pore size; 20.5 $\mathrm{cm} \times 25.5 \mathrm{~cm}$ ) and gas phase in polyurethane foam (PUF) (Callén et al., 2008a). Samples were collected every week from April 7, 2003 to July 5, 2004 on week days, collecting a total of 50 samples. More details regarding the sampling site were given in previous articles (López et al., 2005; Callén et al., 2008b).

\section{$\underline{2.2 \text { Analysis of metals }}$}

The following metals (Al, Ba, Ca, Co, Cr, $\mathrm{Cu}, \mathrm{Fe}, \mathrm{K}, \mathrm{Mg}, \mathrm{Mn}, \mathrm{Na}, \mathrm{Ni}, \mathrm{Pb}, \mathrm{Sr}, \mathrm{V}$, and Zn) were analysed by ICP-OES (JY 2000 Ultrace Horiba) after solubilization of $1 / 4$ of filter with $\mathrm{HNO}_{3}$ according to a procedure previously described (López et al., 2005).

\subsection{Analyses of soluble inorganic ions}

\subsubsection{Sample extraction}

$1 / 8$ of the filter was extracted by ultrasonic bath for 30 minutes in $15 \mathrm{~mL}$ of Milli-Q water. The extract was filtered through a Cameo $(3) \mathrm{N}$ Nylon filter $(0.22 \mu \mathrm{m}$ pore size and $30 \mathrm{~mm}$ filter diameter).

\subsubsection{Analytical technique}

Analyses were carried out by a Dionex ICS2000 ionic chromatograph with Chromeleon version 6.60SP2 software. The anion and cation methods used the AS17 analytical column $(2 \mathrm{~mm} \times 250 \mathrm{~mm})$ and the CS17 analytical column $(3 \mathrm{~mm} \times 250 \mathrm{~mm})$, respectively, as described in the IonPac-AS17 and the IonPac-CS17 manuals. In both 
cases, the detector was a conductivity cell working at $35^{\circ} \mathrm{C}$. An eluent ion suppressor working at $19 \mathrm{~mA}$ (anions) and $62 \mathrm{~mA}$ (cations) was placed before the detector in order to prevent saturation by the background signal.

A total of seven anions $\left(\mathrm{F}^{-}, \mathrm{Cl}^{-}, \mathrm{NO}_{2}{ }^{-}, \mathrm{Br}^{-}, \mathrm{NO}_{3}{ }^{-}, \mathrm{SO}_{4}{ }^{2-}, \mathrm{PO}_{4}{ }^{3-}\right)$ and six cations $\left(\mathrm{Li}^{+}, \mathrm{Na}^{+}\right.$, $\mathrm{NH}_{4}^{+}, \mathrm{K}^{+}, \mathrm{Mg}^{2+}, \mathrm{Ca}^{2+}$ ) were analyzed. The sulphate concentration of marine origin, $\mathrm{mSO}_{4}{ }^{2-}$ was determined indirectly by considering the $\mathrm{Na}^{+}$soluble concentration according to the ratio: $\mathrm{mSO}_{4}{ }^{2-} / \mathrm{Na}^{+}=0.25$ in weight (Duce et al., 1983). The non-sea-

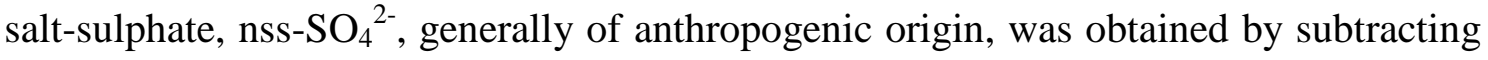
this value to the $\mathrm{SO}_{4}{ }^{2-}$ concentration. The detection and quantification limits were determined according to 3 and 10 times the blank standard deviation (the lowest detection limit for $\mathrm{Br}^{-}: 0.001 \mathrm{mg} \mathrm{L}^{-1}$, the highest detection limit for $\mathrm{Na}^{+}: 0.602 \mathrm{mg} \mathrm{L}^{-1}$ ).

\subsection{PAH analysis}

The following PAH (phenanthrene (Phe), anthracene (An), 2+2/4-methylphenanthrene (2+2/4MePhe), 9-methylphenanthrene (9MePhe), 1-methylphenanthrene (1MePhe), 2,5/2,7-/4,5-dimethylphenanthrene (Dimephe), fluoranthene (Flt), pyrene (Py), benz[a]anthracene (BaA), chrysene (Chry), benzo[b]fluoranthene $(\mathrm{BbF})$, benzo[k]fluoranthene $(\mathrm{BkF})$, benzo[e]pyrene $(\mathrm{BeP})$, benzo[a]pyrene $(\mathrm{BaP})$, indeno[1,2,3cd]pyrene (IcdP), dibenzo[a,h]anthracene (DahA), benzo[ghi]perylene (BghiP) and coronene (Cor) contained in the filter and PUF were quantified according to previous publications using gas chromatography mass-spectrometry mass-spectrometry (GC-MSMS) (Callén et al., 2008a).

\subsection{Quality control and quality assurance}

Analyses of two standard reference materials, SRM 1944 and SRM 1649a, both provided by NIST, were carried out in order to check the analytical accuracy and precision of trace elements, ions and PAH. Measured values were satisfactorily 
comparable to certified values with deviations lower than $30 \%$ with the exception of $\mathrm{Na}$, $16 \%$ and $23 \%$ for all trace elements, ions and $\mathrm{PAH}$, respectively.

\subsection{Models}

PCA-APCS, Unmix and PMF were applied to the Zaragoza data in order to estimate source profiles and contributions. Because there is a lot of bibliography regarding the theoretical aspects of these receptor models, only details that are specific to this application are discussed below.

PCA-APCS was applied to the data using software package SPSS version 11.5. Due to the high number of analysed variables versus the samples number and considering that $n>30+(V+3) / 2$, where $n=$ number of samples and $V=$ number of variables, a total of 35 variables were considered in the PCA (Karar and Gupta, 2007). Prior to statistical analyses, all variables were typified and transformed into a dimensionless standardized form. Once obtained the PCA results, the communalities were checked in order to choose the variables which could provide a more feasible solution. Results from all PCA analyses were evaluated only for factors with eigenvalues higher than unity by adopting Kaiser's criteria. Chemical variables were considered to identify source categories only when factor loadings were $>0.5$ (absolute value).

Unmix 6.0 and PMF 1.1 models were available at EPA site (http://www.epa.gov/heasd/products/unmix/unmix.htm;http://www.epa.gov/heasd/produ cts/pmf/pmf.htm).

In the Unmix model, missing values were represented by the geometric mean concentration of the compound. A value equal to one half the analytic detection limit was used in source apportionment modeling for species with concentrations below the detection limit. Scatterplots of all species versus mass were also useful in choosing those species that influenced the mass yielding well-defined edges and were included in 
the analysis. No influential points were found so that all data were included in the model. The fitting species were chosen using the select initial species function and the suggesting more species function. Numerous attempts were made in order to resolve the number of sources using various sets of fitting species. In general, model inputs of four sources resulted in some blending of sources with very few species included in the model. For these reasons and after several tests, the model identified five sources by including 17 species with the highest correlation between predicted and measured concentrations of PM10 and with standardized residuals between -3 and 3 that will be commented in section 3.2. Efforts to incorporate other species did not lead to feasible solution. The model was set to consider PM10 as the total mass.

Regarding the PMF model, one of the main differences with the models previously described is that PMF considers the uncertainties of variables. The matrix of measurement uncertainties was calculated by considering the detection limit for each variable and the error after comparing results with certified values from SRM. The election of variables and the optimal number of factors was conditioned by the signal to noise ratio $(\mathrm{S} / \mathrm{N})$, the convergence of results between the $\mathrm{Q}$ robust and $\mathrm{Q}$ true, the distribution of residuals for individual compounds and the scatterplots of predicted mass versus the actual mass.

Different runs were carried out by down weighting the species category from "strong" to "weak" to those species with low signal/noise but results did not improve. In this way, a total of 11 variables were excluded by considering them "bad" (PM10, Zn, V, $\mathrm{Co}, \mathrm{Ni}, \mathrm{Cr}, \mathrm{Na}, \mathrm{K}, \mathrm{Mg}, \mathrm{Ca}, \mathrm{PO}_{4}{ }^{3-}$ ) and 32 variables were included by considering them "strong". All samples were considered in the model. In addition, $12 \%$ of the extra modelling uncertainty was considered. 
The theoretical $\mathrm{Q}$ value, identical to the number of data entries, was 1600 . The “optimal" solution was considered to have a Q value near the theoretical Q value and a solution that did not depend on the initial seed suggesting that a stable solution was obtained. The number of factors was increased one by one by considering that if $\mathrm{Q}$ decreases by less than $2 *(n+m)$ when increasing $\mathrm{P}$ by one, then the decrease of $\mathrm{Q}$ is insignificant and increasing $\mathrm{P}$ is not supported, where $\mathrm{n}=$ number of variables, $\mathrm{m}=$ number of samples and $\mathrm{P}=$ number of factors. The nine-factor solution was chosen because an increase from 7 to 8 to 9 factors improved the interpretation of the factor profiles (Figure S1, Supplementary material). The PMF was run with 9 factors and 50 random starting points and with random seed equal to rand as well as with different random seed values. All runs converged finding a similar global minimum, which was quite near the theoretical Q. The robust Q was 1695 and the true Q was 1764.

Once a reasonable solution was found, the uncertainties in the modelled solution were estimated using a bootstrapping technique. A total of 300 bootstrap runs were performed with a minimum r-value for base-boot factor mapping of 0.6 finding that all runs converged. Residuals were also checked to be between -3 and 3 the standard deviation for all species for at least $88 \%$ of the observations.

\section{Results and Discussion}

\subsection{Source apportionment by PCA-APCS}

A total of 35 variables were considered in the PCA with Varimax rotation and a total of eight components were extracted covering $86 \%$ of the data variance (Table S1, Supplementary material). The first factor $\mathrm{PC} 1$ was related to $\mathrm{BaP}, \mathrm{BkF}, \mathrm{BaA}, \mathrm{BbjF}$, Chry, IcdP+DahA, BghiP, Py, Flt, BeP, Cor, Phe and An and it explained 32.6\% of the variance. This factor was associated with the combustion of fossil fuels: coal combustion and coke production (Duval and Friedlander, 1981), natural gas home 
appliances (Rogge et al., 1993) and vehicles emissions (Harrison et al., 1996; Li and Kamens, 1993). The location of the sampling point close to a highway, the presence of near power stations in Escatrón (Zaragoza) and Andorra (Teruel) burning coal, small industrial activities located in the surroundings of the sampling point and the main use of natural gas as home heating justified this factor.

The second factor was related to $1 \mathrm{MePhe}$, DiMePhe, 2+2/4 MePhe, $9 \mathrm{MePhe}$ and it explained $14.3 \%$ of the variance. The high loadings of MePhe have been attributed by different authors to the evaporation of uncombusted petroleum during fuel handling and refueling operations (Kavouras et al., 2001; Simcik et al., 1999). Two petrol stations located close to the sampling area could support this factor that was labeled as evaporative emissions.

The third factor was related to $\mathrm{Cu}, \mathrm{Cr}, \mathrm{Pb}, \mathrm{Mn}, \mathrm{Fe}$ and $\mathrm{Zn}$ explaining $10.7 \%$ of the variance. This factor was considered as industrial activities related to steel manufacturing and production (Cetin et al., 2007; Querol et al., 2007) and traffic emissions (Weckwerth, 2001; Ramadan et al., 2000; Fergussion and Kim, 1991).

The fourth factor was associated with $\mathrm{Ca}^{2+}, \mathrm{nmSO}_{4}{ }^{2-}, \mathrm{K}^{+}$and $\mathrm{Mg}^{2+}$ and it explained $8.3 \%$ of the variance. Non-marine sulphate can have a double origin, anthropogenic due to the oxidation of fossil fuel combustion products or natural origin, mainly related to gypsum, limestone and dolomite as consequence of soil resuspension (Hedge et al., 2007). In fact, gypsum deposits are very abundant in Aragón and there are also important quarries of limestone in Zaragoza and Teruel. These materials are also used as construction materials. This factor was labelled as crustal 1 and related to soil resuspension and abrasions from construction materials such as cement.

The fith factor was related to $\mathrm{Na}^{+}, \mathrm{Mg}^{2+}, \mathrm{Cl}^{-}$and it explained $7.0 \%$ of the total variance. 
This component was associated with marine components and with halite exploitation due to the presence of salt mines localised $35 \mathrm{~km}$ away from the sampling point.

The sixth factor was related to $\mathrm{Co}, \mathrm{Ni}$ and $\mathrm{V}$ and it explained $5.9 \%$ of the total variance. It was considered as fuel-oil combustion (Pacyna, 1986) showing the contribution not only of local pollution sources associated with some industrial processes and some domestic heating systems but also the long-range transport processes from different power stations located in other regions of Spain.

The seventh factor was related to crustal elements $\mathrm{Sr}$ and $\mathrm{Al}$, explaining $3.8 \%$ of the total variance. This factor labelled as crustal 2 was related to clay soils, typical from Aragón area. Finally, the last factor was related to $\mathrm{NO}_{3}{ }^{-}, \mathrm{NH}_{4}{ }^{+}$and slightly to $\mathrm{K}+$ explaining $3.3 \%$ of the total variance. This profile is typical of combustion processes, in particular the biomass burning (Ryu et al., 2007) and it was justified by residual water treatment and paper industries located in the city.

Once the PCA was obtained, the absolute factor scores (AFS) were regressed on the observed PM10 concentration to apportion the particulate matter to each sample (Kumar et al., 2001) (Figure 1). According to this model, $88 \%\left(28.45 \mu \mathrm{g} \mathrm{m}^{-3}\right)$ of the experimental PM10 was explained and the non justified mass in the analysis was the remaining $12 \%\left(3.50 \mu \mathrm{g} \mathrm{m}^{-3}\right)$.

The chemical profile of each element (Figure 2) was also obtained by following the methodology established by Thurston and Spengler (1985). The dependent variable was the concentration of the different chemical species analyzed and the independent variables were the daily contributions of each source. This chemical profile and the PCA allowed the correct identification of the eight factors explained above.

\subsection{Source apportionment by Unmix model}


The model identified five sources using 17 species (PM10, Pb, Mn, Fe, Cl-, $\mathrm{nmSO}_{4}{ }^{2-}$, $\mathrm{Na}^{+}, \mathrm{K}^{+}, \mathrm{Mg}^{2+}, \mathrm{Ca}^{2+}, 2+2 / 4 \mathrm{MePhe}, 9 \mathrm{MePhe}$, 1MePhe, DiMePhe, IcdP+DahA, BghiP, Cor). The following species were discarded by the model according to suggest exclusion $\left(\mathrm{Zn}, \mathrm{V}, \mathrm{Ni}, \mathrm{Cr}, \mathrm{Cu}, \mathrm{Co}, \mathrm{Ba}\right.$ and $\mathrm{PO}_{4}{ }^{3-}$ ) due to specific variances $\mathrm{SV}>0.5$. The minimum correlation coefficient $\left(r^{2}\right)$ was 0.93 with a minimum signal to noise ratio of 2.67 , fulfilling the requirements of this model $\left(r^{2}>0.80\right.$ and signal/noise $\left.>2.0\right)$.

The uncertainties were calculated by Unmix using a bootstrap procedure resampling the data 100 times. The source profiles as mass fractions, the estimated uncertainty in mass fraction and the relative certainty of each species mass fraction are shown in Table S2, Supplementary material. It can be deduced that four of the five sources founded by the model showed a reasonable amount of confidence in source composition with high relative certainty. In this case, the mass attributed to the evaporative emissions, the fourth component mainly associated with methylphenanthrenes, was $0.32 \mu \mathrm{g} \mathrm{m}^{-3}$ and this source was not further considered in the Unmix analysis. This reflected one of the disadvantages of the Unmix model due to its difficulty in identifying small sources with less than $10 \%$ of the total mass (US-EPA, 2004).

The chemical profile for each identified source and its average contribution are shown in Figure 3. Four of the five sources coincided with the sources identified by the PCAAPCS model. These were industry+traffic, marine aerosol, evaporative emissions and crustal 1. A different source associated with IcdP+DahA, BghiP and Cor was obtained by the Unmix model. This factor was associated with heavy duty vehicles. The high contribution of high molecular weight $\mathrm{PAH}$ was considered as heavier oil combustion by Lee et al. (2004). These three compounds are typical markers of traffic emissions (Venkataraman et al., 1994; Harrison et al., 1996; Simcik et al., 1999) and IcdP was associated with diesel emissions (Li and Kamens, 1993). In addition, previous studies 
carried out in Zaragoza showed high concentrations of Cor in areas using diesel as main fuel and with high density of traffic (López et al., 2003). Unmix slightly overestimated the PM10 concentration so that the average modeled value was $33.11 \mu \mathrm{g} \mathrm{m}^{-3}, 103 \%$ of the experimental PM10.

\subsection{Source apportionment by Positive Matrix Factorization}

A total of nine factors were chosen as the optimal number for the PMF model and the contribution of each factor was obtained by regressing the contribution of each factor against the PM10 concentrations (Figure 1). These factors together to the chemical profiles (Figure 4) were associated to different sources: industrial emissions, biomass combustion, crustal 2, evaporative emissions, traffic emissions, combustion of fossil fuels, crustal 1, marine aerosol and heavy duty vehicles. It is worthy saying that PMF was able to distinguish a component associated with $\mathrm{Ba}$ and considered as traffic emissions related to tyre and brake abrasion (Monaci and Bargagli, 2004). The $86 \%$ of the experimental PM10 was explained according to this model, $27.6 \mu \mathrm{g} \mathrm{m}^{-3}$, while the $14 \%$ of the PM10, $4.64 \mu \mathrm{g} \mathrm{m}^{-3}$ was not identified.

\subsection{Comparison of PCA-APCS, Unmix and PMF results}

One of the novelties of this work was focused on the exhaustive characterization of the PM10 in Zaragoza by studying not only the inorganic component of the PM (trace elements and ions) but also studying the organic component of the PM10 (PAH analysis). In addition, three different receptor models were applied to apportion the PM10 in Zaragoza in order to compare results and the adequacy of models.

The comparison of the three models was performed by considering different aspects: the fitting quality between the PM10 measured and the modelled ones, the number and nature of the identified sources, the contribution of each source to the total PM10 as well as the temporal evolution of each identified source. 
The quality of the models was shown by regressing the PM10 modelled for each model against the one measured. It was found that all three models provided good results regarding their ability to reproduce measured PM10 concentrations (Figure S2, Supplementary material) with very similar slopes in all cases but with the PCA model showing the best correlation and the closest slope to the unity. The intercepts were also similar with the lowest one for the PMF model.

An inter-comparison was also performed between the models by plotting the PM10 modelled for each model. Good correlations were found between the three models, in particular PCA-PMF $\left(r^{2}=0.92\right.$, slope $\left.=0.99\right)$ and PMF-Unmix $\left(r^{2}=0.90\right.$, slope $\left.=1.07\right)$. This indicated that these models track the PM10 almost perfectly as well as the mass explained. The worst correlation was found between the PCA and Unmix models. Nevertheless, the $\mathrm{r}^{2}$ was quite good with a value of 0.88 and a slope of 0.81 .

Four common sources were identified by the three models (Figure 1): crustal1, marine, industry+traffic and evaporative emissions. The crustal 1 component, with high correlation coefficients by the three models (Table S3, Supplementary material), showed a good correlation with the PM10 concentration (dashed line in Figure 5a) with high concentration peaks for those dates in which local soil resuspension and NorthAfrican intrusions were produced (de la Cruz, 2008). This fact reflected the importance of considering, in particular areas, the natural contribution of the PM to fulfil the legislation concerning PM10 (Directive 2008/50/EC), especially in Mediterranean countries that can be influenced by long-range transport from North Africa. The temporal contribution of this factor by the three models showed a seasonal behavior at 99\% level of significance with higher concentrations in the warm season as also happened with the PM10 (Figure 5a). The three models identified the marine source and Unmix attributed a higher concentration to this source than the other two models (Table 
1 and Figure 5b). The marine component showed a seasonal trend statistically significant with higher contribution in the cold season due to Atlantic advections. The correlation among the contributions determined by each model was in all cases significant at $99 \%$ level (Table S3, Supplementary material). The contribution of the industry and traffic source was similar according to the three models (Figure 5c). In the case of the PMF model, the contribution of the factor associated with $\mathrm{Ba}$ and related with traffic was also added. No seasonal behavior (Figure 5c) was found as these emissions are produced in a constant way all the year as consequence of the industrial parks surrounding the city as well as the highway close to the sampling point. Regarding traffic, PCA was not able to distinguish the contribution of traffic fuels from the fossil fuel combustion while PMF and Unmix identified independently a factor associated with heavy duty vehicles (Figure 5d). This heavy duty vehicles factor showed maximum peaks for those dates in which the BaP equivalent concentration (BaP-eq) exceeded the value of $1 \mathrm{ng} \mathrm{m}^{-3}$ (de la Cruz, 2008) according to Larsen and Larsen (1998) indicating that traffic is one of the main sources producing PAH. The correlation between the contribution found by the two models was high (Table S3, Supplementary material) and followed a seasonal trend statistically significant with higher concentrations in the cold seasons. The source related with the evaporative emissions from petrol stations (Figure 5e) was identified by the three models but the contribution according to Unmix was quite lower than the obtained by the PCA and PMF and no correlation was found with them (Table S3, Supplementary material). No statistically significant seasonal behavior was found for this source but the average values were higher during the warm season that is quite reasonable with the evaporation processes. 
In addition, the PCA and PMF models were able to distinguish three common sources: a second crustal component mainly related to clays (crustal 2) (Figure 5f) that represented a small percentage of the PM10, a biomass combustion component and a fossil fuel combustion factor. This crustal 2 factor also presented higher concentrations in the warm season at $99 \%$ level of significance with high correlation coefficient between the two models (Table S3, Supplementary material). The biomass combustion factor (Figure 5g) showed a good correlation (Table S3, Supplementary material) between the two models with a statistically significant seasonal trend with higher values in cold season probably due to the lower dispersion capacity of the atmosphere and the influence of the temperature of the $\mathrm{NH}_{4} \mathrm{NO}_{3}$ dissociation in its gaseous species.

The contributions determined by these two models (PCA and PMF) for the fossil fuel combustion factor (Figure 5h) were well correlated. The fossil fuel factor determined by PCA was also correlated with the traffic factor identified by PMF and PCA (Table S3, Supplementary material). This factor showed a statistically significant seasonal trend with higher values in the cold seasons. Although the use of fossil fuel in industrial processes remains constant along the year, the use of natural gas for domestic heating increases during cold seasons. The cold weather also favors the pollutant accumulation due to the lower mixing layer and the photochemical reactions contribute less to PAH transformation due to lower grade of solar radiation. This factors also showed maximum peaks (Figure $5 \mathrm{~h}$ ) for those dates in which the benzo(a)pyrene equivalent (BaP-eq) exceeded $1 \mathrm{ng} \mathrm{m}^{-3}$ (de la Cruz, 2008) corroborating the anthropogenic origin of PAH. Finally, the PCA was able to identify a factor related with fuel-oil (Figure 5i). The fueloil is used as fuel in some power stations and in domestic heating systems. In Zaragoza there are no power stations using this fuel but this factor could be identified in longrange transport episodes from Spanish areas in which power stations are located (de la 
Cruz, 2008). In fact, although higher concentrations of this factor were found in cold season, the difference with the warm season was not statistically significant because of these long-range transport episodes.

The differences regarding the identified sources by each receptor model were mainly due to the considerations of the models to choose the species selected as variables. PCA and PMF identified similar sources although the first one was not able to distinguish the fossil fuel factor from the heavy duty vehicles factor. Because the communalities and the regression for $\mathrm{Co}, \mathrm{Ni}$ and $\mathrm{V}$ were good according to PCA-APCS, these variables were included in the model and a source related to traffic was identified. Unmix was more limited and identified a lower number of sources, five versus eight and nine by the PCA and PMF models, respectively. This limitation is related to the model because it does not take into account the uncertainty in the experimental data but it is very sensitive to this one, excluding some variables. In this case, Unmix excluded species where most of the measurements were replaced by half the detection limit. The Unmix solution is highly dependant on the species that are selected. On the other hand, this model showed problems to identify those sources contributing with a low percentage to the total mass corroborating the weakness of Unmix related to identify ubiquitous sources, infrequent sources and relatively small sources (contributing less than about $10 \%$ to the total mass). Nevertheless, the sources with the highest contribution to the total PM10 were included among the identified sources. It is also worthy saying that although the PAH concentrations in weight represent a low percentage to the total PM10 (de la Cruz, 2008), two of the five sources explaining the PM10 are attributed to PAH and constitute the $16 \%$ of the total PM10 concentration.

With regard to the total of PM10 explained by each model (Table 1), the three models explained similar percentage of the experimental PM10 and Unmix was the only model 
that slightly overestimated the concentration. This could be interpreted in terms that Unmix was the best model regarding the explained mass. However, in this work two essential components of the PM were not analysed, the organic carbon and the elemental carbon. In this way, it was considered that Unmix results were less realistic and PCA and PMF, both showing similar results, were more adequate to explain the Zaragoza PM10.

The models' performance was also evaluated by estimating the correlation coefficients and the error percentages between the estimated and experimental PM10 concentrations (Table 2). The correlation coefficients were, in general, quite high predicting quite well the temporal variations of the analysed species. PMF was the model with the lowest error in the determination. It always modelled lower concentrations than the experimental ones in the range $1-37 \%$ (except for Phe). PCA overestimated the concentration of some species and underestimated the concentration of others with errors up to $87 \%$ for Ni. Unmix overestimated the concentration of all species and although the $\mathrm{r}^{2}$ were quite good, the errors, always in excess, were quite considerable. These large errors in the model might have been caused by the model itself (e.g. uncertainties parameters) and the data quality. While PCA-APCS differs from the Unmix and PMF models in not having a non-negativity constraint, Unmix provides a relatively coarse means of down-weighting outliers and PMF utilizes point-by-point estimates of errors in the data allowing down weighting of missing observations and outliers. That could be one of the reasons why PMF model provided better results than the Unmix model. For the two models that do not require measurement of uncertainty, PCA-APCS was much better than the Unmix model.

\section{Conclusions}


The particulate matter of Zaragoza city was apportioned for the first time by three multivariate receptor models based on factor analysis: PCA-APCS, Unmix and PMF contributing to the knowledge of the Spanish particulate matter. The similarity between the three models was proved with the correlation coefficients and the percentage of PM10 explained. The three applied models were able to identify the main sources contributing to the PM10. While PCA and PMF were more specific in the source identification with eight and nine different factors, respectively, Unmix was more conservative and some sources could not be differentiated. A reasonable agreement between PCA and PMF was found, with both models identifying the same sources and with good correlations for the same identified sources. The greater requirements of measure of uncertainty in PMF permitted to obtain better results than with the other two models: PCA-APCS and Unmix. However, the application of three models to the PM10 Zaragoza data allowed: 1) the identification of a reasonable number of sources in agreement with the sampling point, 2) the corroboration of the main identified sources and 3) the possibility of separating some sources related with traffic that could not be discerned by other models, providing more complete information for the apportionment of the Zaragoza PM10 than using only one model.

\section{Acknowledgements}

Authors would like to thank Aula Dei-CSIC (R. Gracia) for providing the meteorological data, the Government of Aragon (DGA) for the grant to M.T.C, the CSIC for the JAE post-doct contract to J.M.L and the Spanish Government for the Ramón y Cajal contract to M.V.N.

\section{Appendix A. Supplementary material}

Supplementary data associated with this article can be found, in the online version, at:

\section{References}


Begum, A.B., Kim, E., Biswas, S.K., Hopke, P.K., 2004. Investigation of sources of atmospheric aerosol at urban and semi-urban areas in Bangladesh. Atmos. Environ. 38, 3025-3038.

Callén, M.S., de la Cruz, M.T., López, J.M., Murillo, R., Navarro, M.V., Mastral, A.M., 2008a. Some inferences on the mechanism of atmospheric gas/particle partitioning of polycyclic aromatic hydrocarbons (PAH) at Zaragoza (Spain). Chemosphere 73, 1357-1365.

Callén, M. S., de la Cruz, M. T., López, J. M., Murillo, R., Navarro, M. V., Mastral, A. M., 2008b. Long-range atmospheric transport and local pollution sources on $\mathrm{PAH}$ concentrations in a South European urban area. Fulfilling of the European Directive. Water Air Soil Poll. 190, 1-4.

Cetin, B., Yatkin, S., Bayram, A., Odabasi, M., 2007. Ambient concentrations and source apportionment of PCBs and trace elements around an industrial area in Izmir, Turkey. Chemosphere 69, 1267-1277.

Chow, J., Watson, J., 2002. Review of PM2.5 and PM10 apportionment for fossil fuel combustion and other sources by the chemical mass balance receptor model. Energy Fuels 16, 222-260.

Cooper, J.A., Watson, J.G., Huntzicker, J.J., 1984. The effective variance weighting for least squares calculations applied to the mass balance receptor model. Atmos. Environ. 18, 1347-1355.

Directive 2008/50/EC of the European parliament and of the council of 21 May 2008 on ambient air quality and cleaner air for Europe.

Duce, R.A., Arimoto, B.J., Ray, B.J., Unni, C.K., Harder, P.J., 1983, Atmospheric trace elements at Enewetak Atoll: 1, Concentrations, sources and temporal variability. J. Geophys. Res. 88, 5321-5342.

Duval, M.M., Friedlander, S.K., 1981. Source resolution of polycyclic aromatic hydrocarbons in the Los Angeles atmosphere application of a CMB with first-order decay. U.S. EPA Report EPA-600/2- 81-161. Washington.

Fergussion, J.E., Kim, N.D., 1991. Trace elements in street and house dust: source and speciation. Sci. Total Environ. 100, 125-150.

García, J.H., Li, W-W., Cárdenas, N., Arimoto, R., Walton, J., Trujillo, D., 2006. Determination of PM2.5 sources using time-resolved integrated source and receptor. Chemosphere 65, 2018-2027.

Gildemeister, A.E., Hopke, P.K., Kim, E., 2007. Sources of fine urban particulate matter in Detroit, MI. Chemosphere 69, 1064-1074.

Harrison, R. M., Smith, D. J. T., Luhana, L., 1996. Source apportionment of atmospheric polycyclic aromatic hydrocarbons collected from an urban location in Birmingham, U.K. Environ. Sci. Technol. 30, 825-832. 
Hegde, P., Sudheer, A.K., Sarin, M.M., Manjunatha, B.R., 2007. Chemical characteristics of atmospheric aerosols over southwest coast of India. Atmos. Environ. $41,7751-7766$.

Henry R.C., 2003. Multivariate receptor modeling by $\mathrm{N}$-dimensional edge detection. Chemometr. Intell. Lab. 65, 179-189. $255-265$.

Hopke, P.K., 2003. Recent developments in receptor modeling. J. Chemom. 17,

Hopke, P.K., Ito, K., Mar, T., Christensen, W.F., Eatough, D.J., Henry, R.C., Kim, E., Laden, F., Lall, R., Larson, T.V., Liu, H., Neas, L., Pinto, J., Stolzel, M., Suh, H., Paatero, P., Thurston, G.D., 2006. Intercomparison of source apportionment results. J. Expo. Sci. Envi. Epid. 16, 275-286.

IonPac-AS17 Manual (http://www.dionex.com/en-us/webdocs/4359_3152902_AS17_V17.pdf).

IonPac-CS17 Manual (http://www.dionex.com/en-us/webdocs/4392_3187704_CS17_Manual_V26.pdf).

Karar, K., Gupta, A.K., 2007. Source apportionment of $\mathrm{PM}_{10}$ at residential and industrial sites of an urban region of Kolkata, India. Atmos. Res. 84, 30-41.

Kavouras, I.G., Koutrakis, P., Tsapakis, M., Lagoudaki, E., Stephanou, E.G., Von Baer, D., Oyola, P., 2001. Source apportionment of urban particulate aliphatic and polynuclear aromatic hydrocarbons $(\mathrm{PAH})$ using multivariate methods. Environ. Sci. Technol. 35, 2288-2294.

Ke, L., Liu, W., Wang, Y., Russell, A.G., Edgerton, E.S., Zheng, M., 2008. Comparison of PM2.5 source apportionment using positive matrix factorization and molecular marker-based chemical mass balance. Sci. Total Environ. 394, 290-302.

Kumar, A.V., Patil, R.S., Nambi, K.S.V., 2001. Source apportionment of suspended particulate matter at two traffic junctions in Mumbai, India. Atmos. Environ. $35,4245-4251$.

Larsen, J.C., Larsen, P.B., 1998. Chemical carcinogens. In: Hester, R.E., Harrison, R.M., editors. Air pollution and health. Cambridge, UK: The Royal Society of Chemistry; 33-56.

Lee, J.H., Gigliotti, C.L., Offenberg, J.H., Eisenreich, S.J., Turpin, B.J., 2004. Sources of polycyclic aromatic hydrocarbons to the Hudson River Airshed. Atmos. Environ. 38, 5971-5981.

Li, C., Kamens, R.M., 1993. The use of PAH as source signatures in receptor modeling. Atmos. Environ. A, 27, 523-532. 
López, J.M., Callén, M.S., García, T., Murillo, R., Navarro, M.V., Mastral, A.M., 2003. Spatial and temporal evolution of atmospheric PAH concentration in Zaragoza, Spain. Sci. Total Environ. 307, 111-124.

López, J.M., Callén, M.S., Murillo, R., Garcia, T, Navarro, M.V., de la Cruz, M.T., Mastral, A.M., 2005. Levels of selected metals in ambient air PM10 in an urban site of Zaragoza (Spain). Environ. Res. 99, 58-67.

Monaci, F., Bargagli, R., 2004. Barium and other trace metals as indicators of vehicle emissions. Water Air Soil Poll. 100, 89-98.

Olson, D.A., Norris, G.A., 2008. Chemical characterization of ambient particulate matter near the World Trade Centre: Source apportionment using organic and inorganic source markers. Atmos. Environ. 42, 7310-7315.

Paatero, P., Tapper, U., 1993. Analysis of different modes of factor. Analysis as least squares problems. Chemometr. Intell. Lab. 18, 183-194.

Paatero, P., 1997. Least squares formulation of robust, non-negative factor analysis. Chemom. Intell. Lab. Syst. 37, 23-35.

Paatero, P., 1999. The multilinear engine - a table-driven least squares program for solving multilinear problems, including the n-way parallel factor analysis model. $\mathrm{J}$. Comput. Graph. Stat. 8, 854-888.

Pacyna, J.M., 1986. Atmospheric trace elements from natural and anthropogenic sources. In: Nriagu, J.O, Davidson, E.I. (Eds.), Toxic Metals in the Environment. John Wiley, London, pp. 33-52.

PMF model (http://www.epa.gov/heasd/products/pmf/pmf.htm).

Querol, X., Viana, M., Alastuey, A., Amato, F., Moreno, T., Castillo, S., Pey, J., de la Rosa, J., Sánchez de la Campa, A., Artíñano, B., Salvador, P., García Dos Santos S., Fernández-Patier, R., Moreno-Grau, S., Negral, L., Minguillón, M.C., Monfort, E., Gil, J.I., Inza, A., Ortega, L.A., Santamaría, J.M., Zabalza, J., 2007. Source origin of trace elements in PM from regional background, urban and industrial sites of Spain. Atmos. Environ. 41, 7219-7231.

Ramadan, Z., Song, X.-H., Hopke, P.K., 2000. Identification of sources of Phoenix aerosol by positive matrix factorization. J. Air Waste Manag. Assoc. 50, 13081320.

Rogge, W.F.; Hildemann, L.M.. Mazurek, M.A., 1993. Sources of fine organic aerosol. 5. Natural gas home appliances. Environ. Sci. Technol. 27, 2736-2744.

Ryu, S.Y., Kwon, B.G., Kim, Y.J., 2007. Characteristics of biomasa burning aerosol and its impact on regional air quality in the summer of 2003 at Gwangju, Korea. Atmos. Res. 84, 362-373. 
Simcik, M. F., Eisenreich, S. J., Lioy, P. J., 1999. Source apportionment and source/sink relationships of PAH in the coastal atmosphere of Chicago and Lake Michigan. Atmos. Environ. 33, 5071-5079.

Song, Y., Xie, S., Zhang, Y., Zeng, L., Salmon, L.G., Zheng, M., 2006a. Source apportionment of PM2.5 in Beijing using principal component analysis/absolute principal component scores and Unmix. Sci. Total Environ. 372, 278-286.

Song, Y., Zhang, Y., Xie, S., Zeng, L., Zheng, M., Salmon, L.G., et al. 2006b. Source apportionment of PM2.5 in Beijing by positive matrix factorization. Atmos. Environ. 40, 1526-1537.

Thurston, G.D., Spengler, J.D., 1985. A quantitative assessment of source contributions to inhalable particulate matter pollution in metropolitan Boston, Atmos. Environ. 19, 9-25.

Unmix model (http://www.epa.gov/heasd/products/unmix/unmix.htm).

US-EPA (United States Environmental Protection Agency), 2004. Receptor model analyses of aerosol PM2.5 data from the improve monitor at Denali National Park. Environmental Protection Agency Region-10, Office of Environmental Assessment, 1200 Seattle, Technical Report 910-R-03-004.

Venkataraman, C., Lyons, J.M., Friedlander, S.K., 1994. Size distribution of aromatic hydrocarbons and elemental carbon 1. Sampling measurement methods and source characterization. Environ. Sci. Technol. 28, 555-562.

Viana, M., Pandolfia, M., Minguillón, M.C., Querol, X., Alastuey, A., Monfort, E., Celades, I., 2008. Inter-comparison of receptor models for PM source apportionment: case study in an industrial area. Atmos. Environ. 42, 3820-3832.

Weckwerth, G., 2001. Verification of traffic emitted aerosols components in the ambient air of Cologne (Germany). Atmos. Environ. 35, 5525-5536. 
Table 1. Sources and source contributions $\left(\mu \mathrm{g} \mathrm{m}^{-3}\right)$ calculated by the three receptor models.

\begin{tabular}{llll}
\hline & PCA-APCS & Unmix & PMF \\
Crustal 1 & $16.61(52 \%)$ & $20.95(65 \%)$ & $12.56(39 \%)$ \\
Marine & $1.28(4 \%)$ & $3.22(10 \%)$ & $2.20(7 \%)$ \\
Industry+traffic & $2.73(8 \%)$ & $2.90(9 \%)$ & $0.57^{\mathrm{a}}(2 \%)$ \\
Evaporative emissions & $2.12(7 \%)$ & $0.32(<1 \%)$ & $5.65(18 \%)$ \\
Crustal 2 & $1.44(4 \%)$ & & $0.45(1 \%)$ \\
Biomass combustion & $1.63(5 \%)$ & & $2.10(6 \%)$ \\
Fossil fuel combustion & $1.04(3 \%)$ & & $1.80(6 \%)$ \\
Heavy duty vehicles & & $4.84(15 \%)$ & $2.25(7 \%)$ \\
Fuel oil & $1.61(5 \%)$ & & \\
Determined & $28.45(88 \%)$ & $33.11(103 \%)$ & $27.60(86 \%)$ \\
a The traffic factor associated with Ba in the PMF model was added to the industry+traffic factor.
\end{tabular}


Table 2. Concentration of each component in $\mathrm{ng} \mathrm{m}^{-3}\left(\mu \mathrm{g} \mathrm{m}^{-3}\right.$ for the PM10) obtained by experimental determination and by modelling with PCA-APCS, PMF and Unmix model ( $\mathbf{r}^{2}=$ correlation coefficient).

\begin{tabular}{|c|c|c|c|c|c|c|c|c|c|c|}
\hline & \multirow[b]{2}{*}{ Experimental } & \multicolumn{3}{|c|}{ PCA-APCS } & \multicolumn{3}{|c|}{ PMF } & \multicolumn{3}{|c|}{ Unmix } \\
\hline & & Modelled & $\mathbf{r}^{2}$ & $\%$ error & Modelled & $\mathbf{r}^{2}$ & $\%$ error & Modelled & $\mathbf{r}^{2}$ & $\%$ error \\
\hline PM10 & 32.24 & 28.45 & 0.79 & -12 & 27.60 & 0.75 & -14 & 33.11 & 0.77 & 3 \\
\hline Al & 2683 & 3570 & 0.82 & 33 & 2335 & 0.89 & -13 & & & \\
\hline Co & 6.82 & 11.56 & 0.72 & 70 & & & & & & \\
\hline $\mathrm{Cr}$ & 6.51 & 5.58 & 0.81 & -14 & & & & & & \\
\hline $\mathbf{C u}$ & 34.58 & 27.93 & 0.83 & -19 & 30.04 & 0.45 & -13 & & & \\
\hline $\mathbf{F e}$ & 620.2 & 616.5 & 0.82 & -1 & 594.5 & 0.81 & -4 & 601.0 & 0.74 & -3 \\
\hline Mn & 14.42 & 14.65 & 0.85 & 2 & 13.79 & 0.83 & -4 & 14.06 & 0.86 & -2 \\
\hline $\mathrm{Ni}$ & 11.19 & 20.92 & 0.79 & 87 & & & & & & \\
\hline $\mathbf{P b}$ & 13.20 & 11.74 & 0.79 & -11 & 11.81 & 0.92 & -11 & 15.65 & 0.99 & 19 \\
\hline $\mathbf{S r}$ & 16.92 & 15.68 & 0.80 & -7 & 14.47 & 0.75 & -14 & & & \\
\hline $\mathbf{V}$ & 11.84 & 12.90 & 0.61 & 9 & & & & & & \\
\hline $\mathbf{Z n}$ & 176.3 & 285.1 & 0.67 & 62 & & & & & & \\
\hline $\mathrm{Cl}^{-}$ & 685.8 & 1039 & 0.93 & 52 & 573.8 & 0.90 & -16 & 823.7 & 0.74 & 20 \\
\hline $\mathrm{NO}_{3}^{-}$ & 2677 & 2722 & 0.83 & 2 & 2550 & 0.93 & -5 & & & \\
\hline $\mathrm{nmSO}_{4}{ }^{2-}$ & 3919 & 4546 & 0.81 & 16 & 3511 & 0.65 & -10 & 5126 & 0.88 & 31 \\
\hline $\mathrm{Na}^{+}$ & 618.8 & 581.5 & 0.88 & -6 & 614.5 & 0.92 & -1 & 902.2 & 0.58 & 46 \\
\hline $\mathrm{NH}_{4}^{+}$ & 580.7 & 620.1 & 0.89 & 7 & 546.9 & 0.88 & -6 & & & \\
\hline $\mathbf{K}^{+}$ & 243.4 & 207.8 & 0.73 & -15 & 236.7 & 0.76 & -3 & 294.0 & 0.48 & 21 \\
\hline $\mathrm{Mg}^{2+}$ & 69.08 & 87.69 & 0.92 & 27 & 66.74 & 0.95 & -3 & 112.4 & 0.63 & 63 \\
\hline $\mathrm{Ca}^{2+}$ & 1228 & 1309 & 0.92 & 7 & 1167 & 0.83 & -5 & 1678 & 0.80 & 37 \\
\hline 2+2/4MePhe & 0.67 & 0.72 & 0.94 & 7 & 0.64 & 0.90 & -4 & 0.8 & 0.90 & 19 \\
\hline 9MePhe & 0.86 & 0.90 & 0.93 & 5 & 0.83 & 0.88 & -3 & 1.17 & 0.93 & 36 \\
\hline 1MePhe & 0.71 & 0.69 & 0.94 & -3 & 0.68 & 0.92 & -4 & 0.94 & 0.95 & 32 \\
\hline
\end{tabular}




\begin{tabular}{|c|c|c|c|c|c|c|c|c|c|c|}
\hline DiMePhe & 0.70 & 0.77 & 0.77 & 10 & 0.62 & 0.74 & -11 & 0.7 & 0.80 & 0 \\
\hline Phe & 2.30 & 3.87 & 0.76 & 68 & 2.46 & 0.70 & 7 & & & \\
\hline An & 0.46 & 0.48 & 0.75 & 4 & 0.40 & 0.73 & -13 & & & \\
\hline Flt & 1.06 & 1.07 & 0.88 & 1 & 0.96 & 0.84 & -9 & & & \\
\hline $\mathbf{P y}$ & 1.12 & 1.00 & 0.90 & -11 & 1.06 & 0.88 & -5 & & & \\
\hline Chry & 0.41 & 0.44 & 0.87 & 7 & 0.26 & 0.91 & -37 & & & \\
\hline $\mathbf{B a A}$ & 0.33 & 0.53 & 0.95 & 61 & 0.36 & 0.78 & 9 & & & \\
\hline BbF & 0.47 & 0.51 & 0.93 & 9 & 0.42 & 0.95 & -11 & & & \\
\hline BkF & 0.13 & 0.13 & 0.95 & 0 & 0.12 & 0.96 & -8 & & & \\
\hline BaP & 0.29 & 0.36 & 0.96 & 24 & 0.22 & 0.63 & -24 & & & \\
\hline BeP & 0.27 & 0.29 & 0.80 & 7 & 0.24 & 0.95 & -11 & & & \\
\hline IcdP+DahA & 1.08 & 1.70 & 0.89 & 57 & 0.93 & 0.94 & -14 & 2.04 & 0.93 & 89 \\
\hline BghiP & 1.02 & 1.23 & 0.83 & 21 & 0.98 & 0.92 & -4 & 1.65 & 0.94 & 62 \\
\hline Cor & 1.47 & 2.18 & 0.90 & 48 & 1.28 & 0.81 & -13 & 2.45 & 0.87 & 67 \\
\hline
\end{tabular}




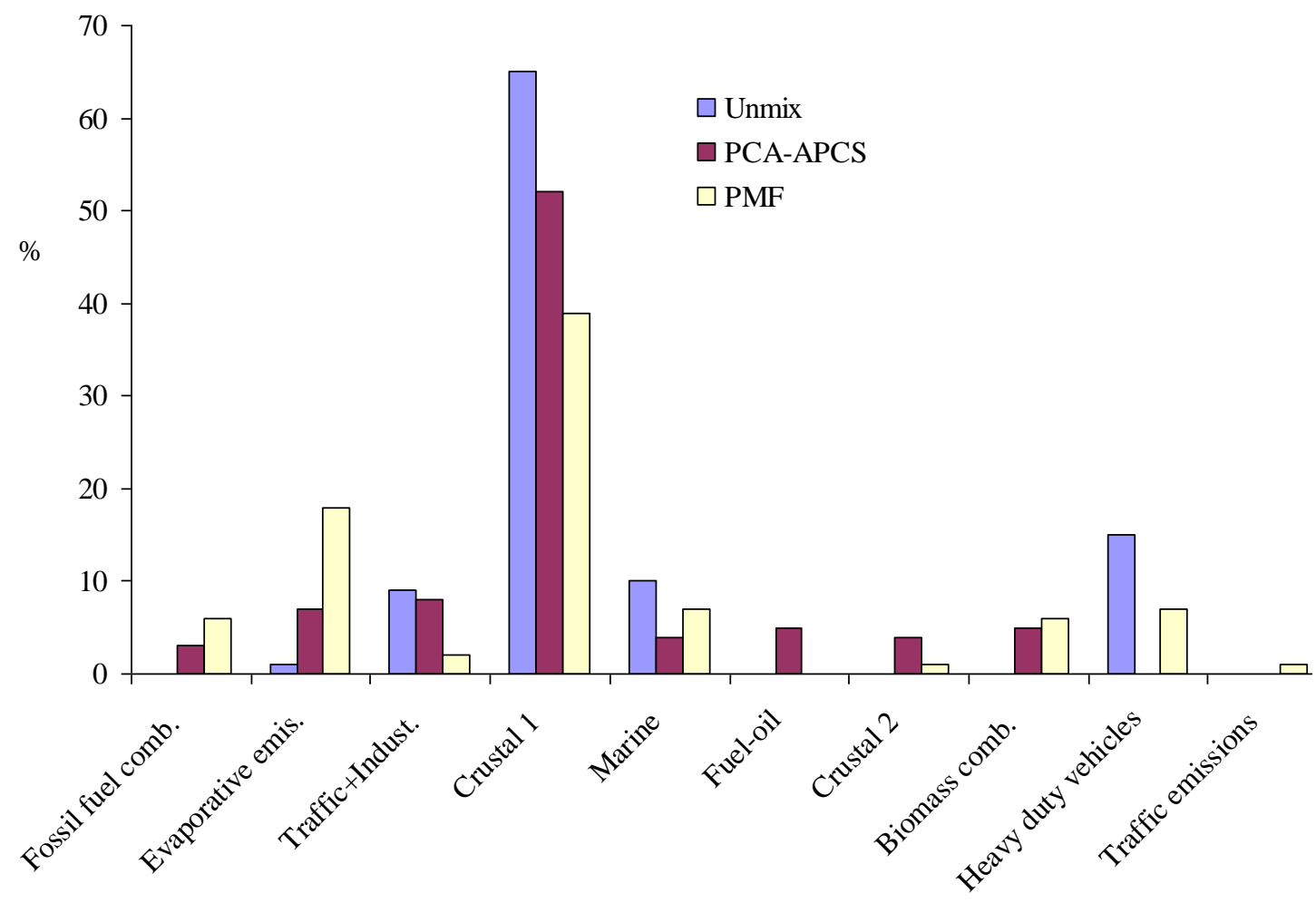

Fig. 1. Percentage of contribution of sources to the average concentration of PM10 at Zaragoza obtained by Unmix, PCA-APCS and PMF models. 

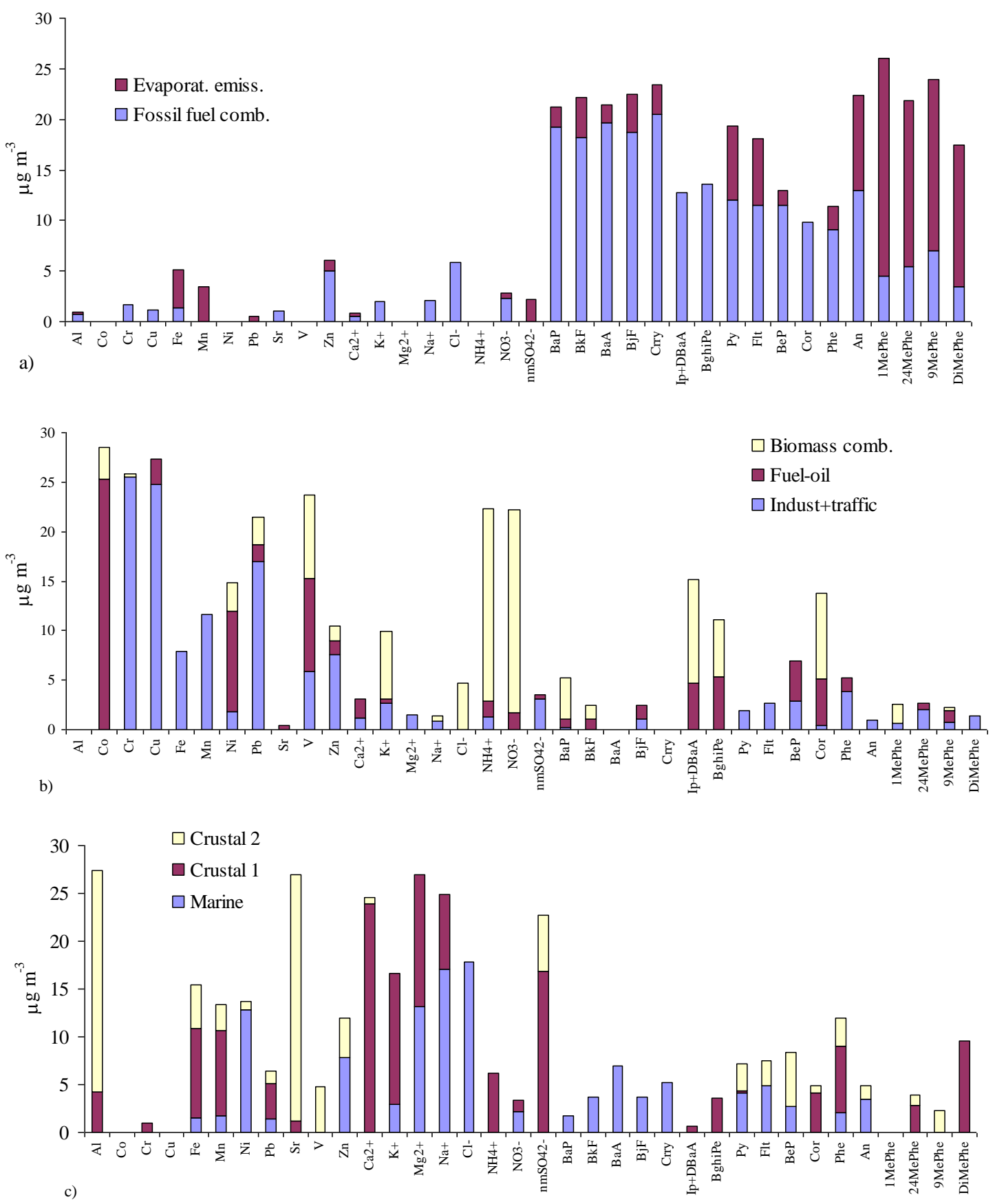

Fig. 2. Contribution of the selected species obtained by PCA-APCS $\left(\mu \mathrm{g} \mathrm{m}^{-3}\right)$ to the PM10 for the different factors: a) evaporative emissions, fossil fuel combustion, b) biomass combustion, fuel-oil, industry+traffic and c) crustal 1, crustal 2 and marine. 


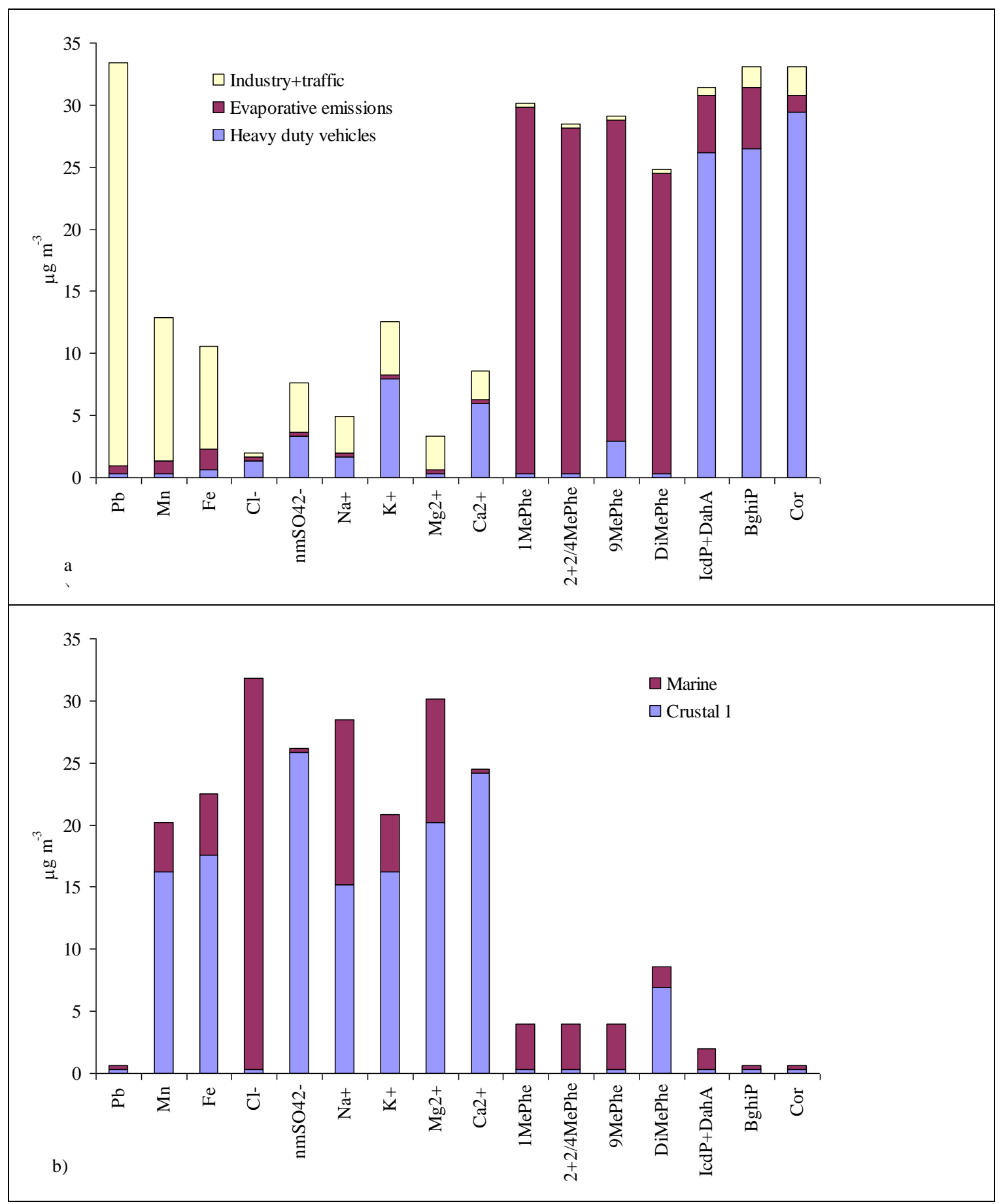

Fig. 3. Contribution of the selected species obtained by Unmix $\left(\mu \mathrm{g} \mathrm{m}^{-3}\right)$ to the PM10 for the different factors: a) industry+traffic, evaporative emissions, heavy duty vehicles and b) marine and crustal 1. 


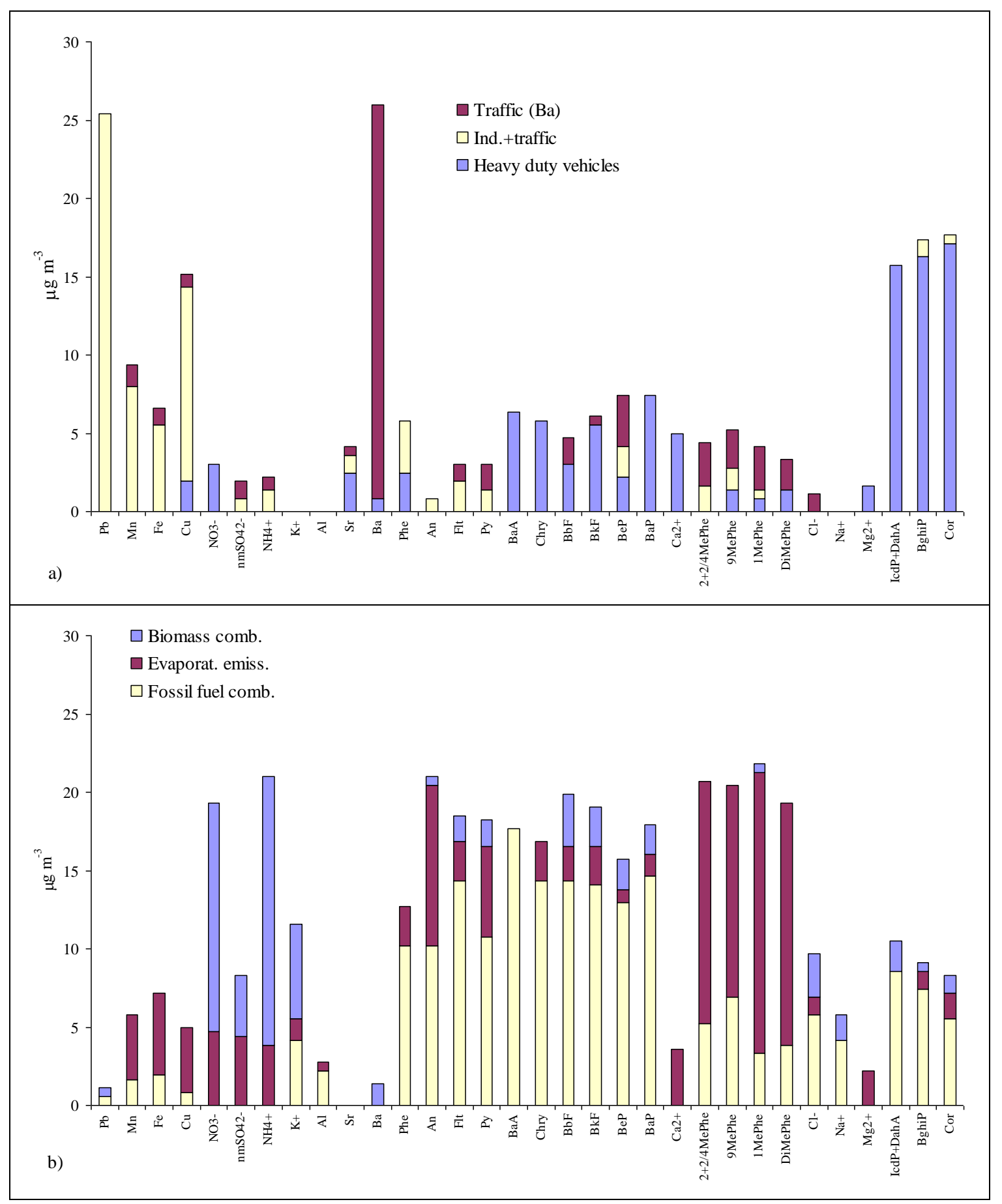




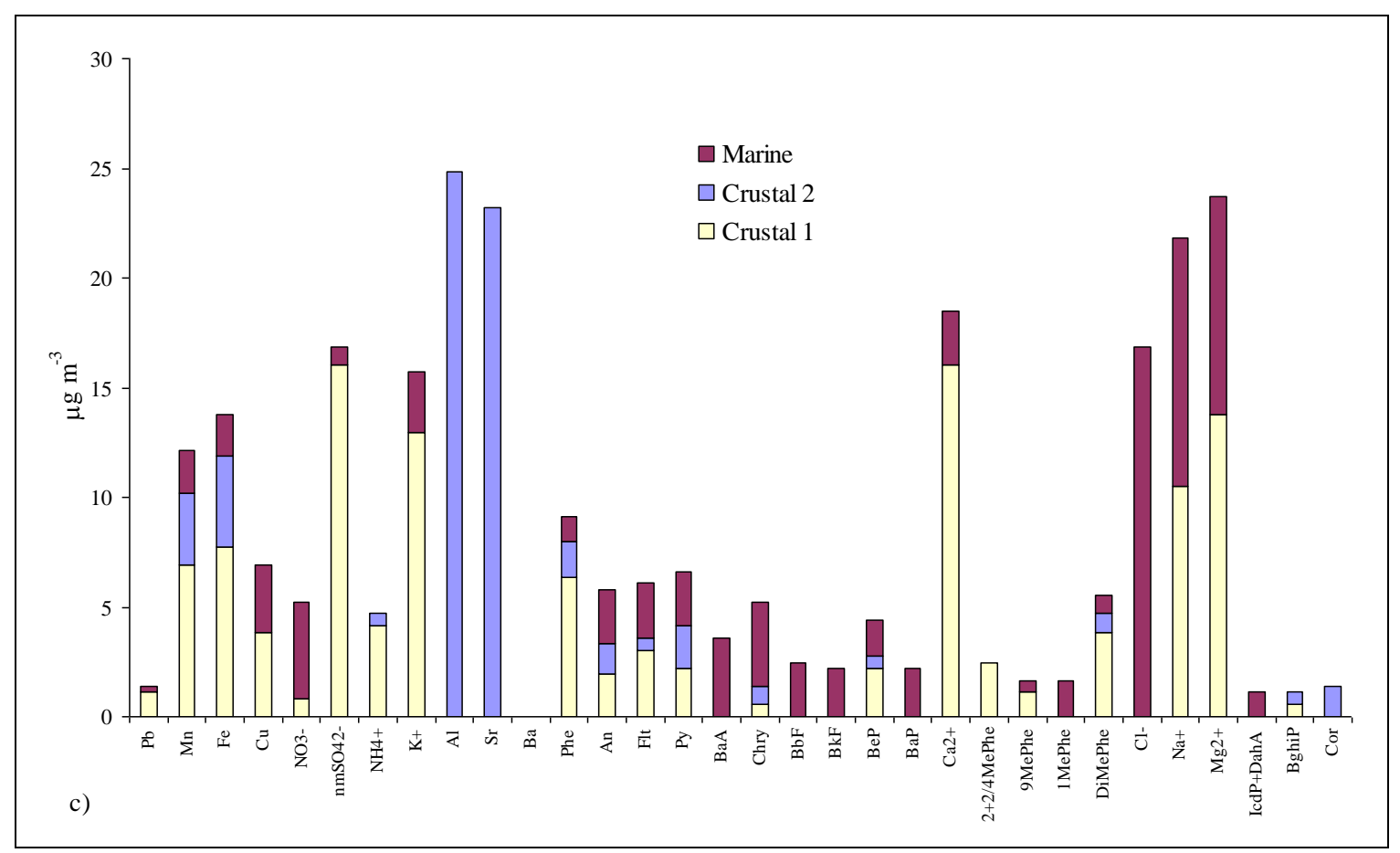

Fig. 4. Contribution of the selected species obtained by PMF $\left(\mu \mathrm{g} \mathrm{m}^{-3}\right)$ to the PM10 for the different factors: a) traffic, industry+traffic, heavy-duty vehicles, b) biomass combustion, evaporative emissions, fossil fuel combustion and c) crustal 1, crustal 2 and marine. 


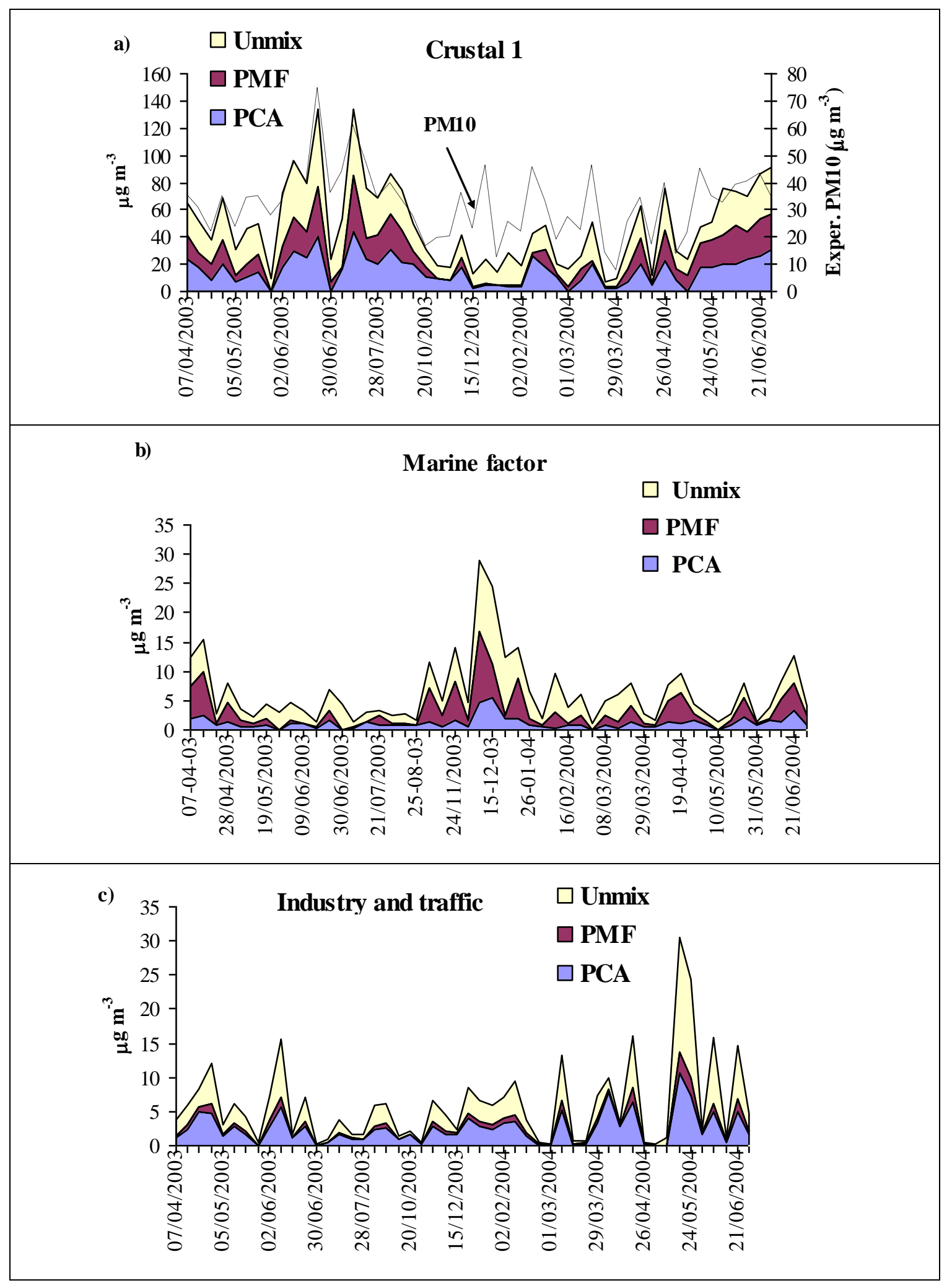




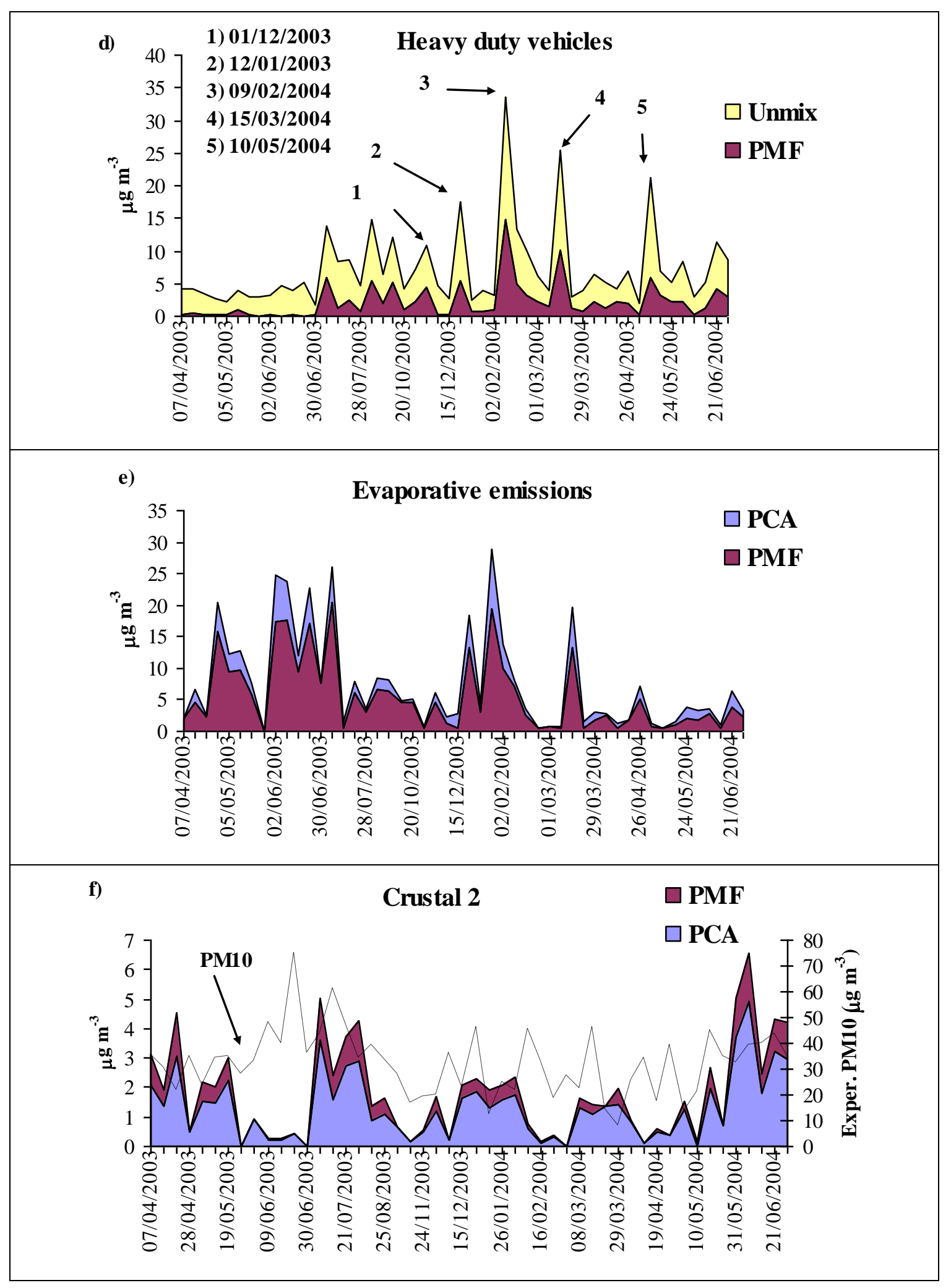




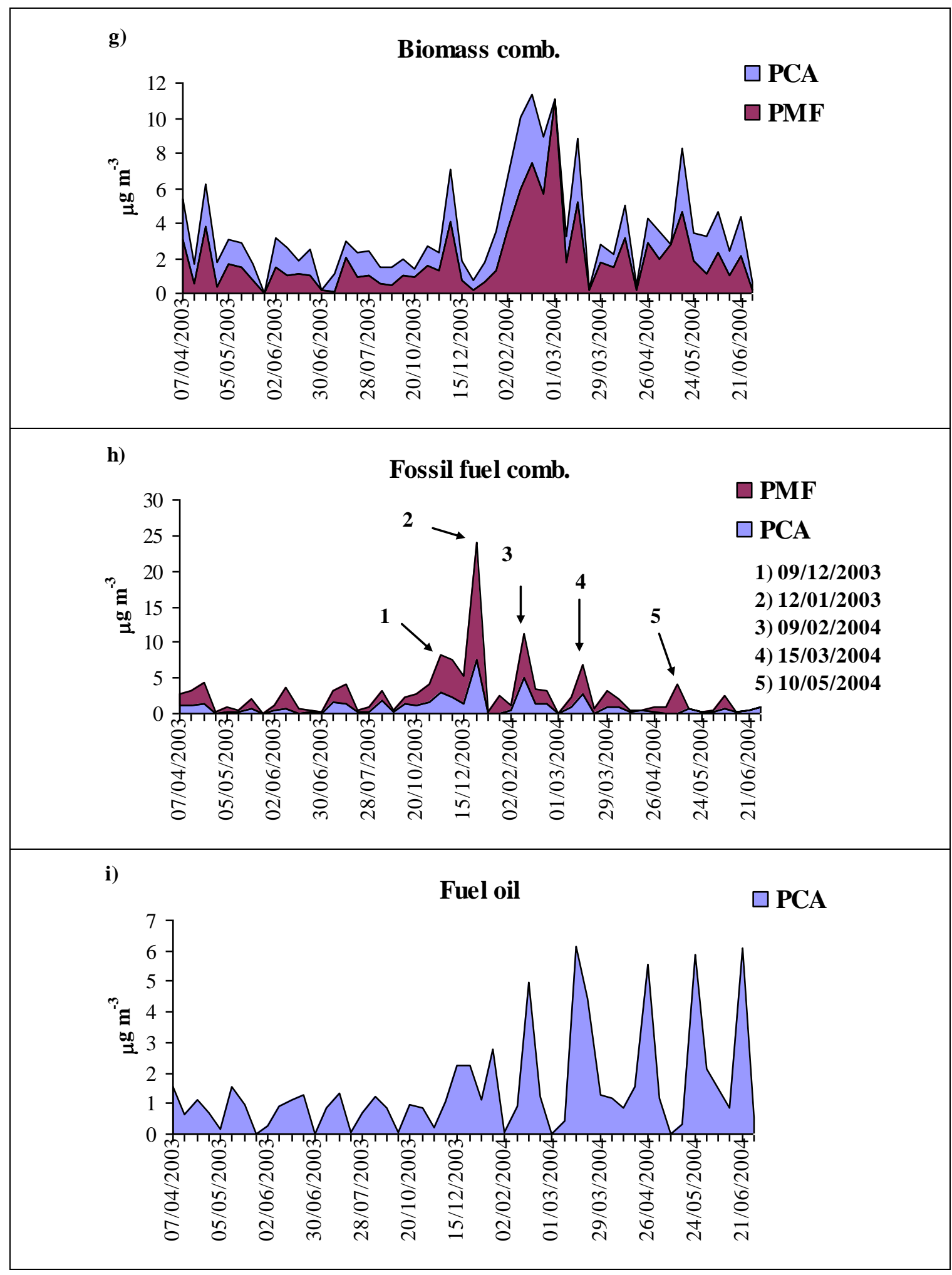

Fig. 5. Temporal evolution of the identified sources $\left(\mu \mathrm{g} \mathrm{m}^{-3}\right)$ for the three receptor models: a) crustal 1 , b) marine, c) industry and traffic, d) heavy duty vehicles, e) evaporative emissions, f) crustal 2 g) biomass combustion, h) fossil fuel combustion and i) fuel-oil. 


\section{SUPPLEMENTARY MATERIAL}

Table S1. Principal Component Analysis after Varimax rotation for the selected components analysed in the PM10 in Zaragoza sampling from July 2001 to July 2002. Only factor loading values greater than 0.5 are shown.

\begin{tabular}{|c|c|c|c|c|c|c|c|c|c|}
\hline & PC1 & PC2 & PC3 & PC4 & PC5 & PC6 & PC7 & PC8 & Communalities \\
\hline $\mathrm{BaP}$ & 0.96 & & & & & & & & 0.95 \\
\hline $\mathrm{BkF}$ & 0.92 & & & & & & & & 0.90 \\
\hline $\mathrm{BaA}$ & 0.91 & & & & & & & & 0.94 \\
\hline $\mathrm{BbjF}$ & 0.91 & & & & & & & & 0.89 \\
\hline Chry & 0.85 & & & & & & & & 0.84 \\
\hline IcdP+DahA & 0.84 & & & & & & & & 0.91 \\
\hline BghiP & 0.83 & & & & & & & & 0.91 \\
\hline Py & 0.83 & & & & & & & & 0.90 \\
\hline Flt & 0.81 & & & & & & & & 0.90 \\
\hline $\mathrm{BeP}$ & 0.81 & & & & & & & & 0.78 \\
\hline Cor & 0.73 & & & & & & & & 0.87 \\
\hline Phe & 0.72 & & & & & & & & 0.75 \\
\hline An & 0.67 & & & & & & & & 0.79 \\
\hline 1MePhe & & 0.94 & & & & & & & 0.95 \\
\hline $2+2 / 4 \mathrm{MePhe}$ & & 0.90 & & & & & & & 0.94 \\
\hline 9MePhe9 & & 0.86 & & & & & & & 0.94 \\
\hline DiMePhe & & 0.81 & & & & & & & 0.81 \\
\hline $\mathrm{Cu}$ & & & 0.90 & & & & & & 0.84 \\
\hline $\mathrm{Cr}$ & & & 0.89 & & & & & & 0.83 \\
\hline $\mathrm{Pb}$ & & & 0.85 & & & & & & 0.81 \\
\hline $\mathrm{Mn}$ & & & 0.75 & & & & & & 0.88 \\
\hline $\mathrm{Fe}$ & & & 0.58 & & & & & & 0.89 \\
\hline $\mathrm{Zn}$ & & & & & & & & & 0.67 \\
\hline $\mathrm{Ca}^{2+}$ & & & & 0.92 & & & & & 0.88 \\
\hline $\mathrm{nmSO}_{4}{ }^{2-}$ & & & & 0.73 & & & & & 0.80 \\
\hline $\mathrm{K}^{+}$ & & & & 0.70 & & & & & 0.77 \\
\hline $\mathrm{Na}^{+}$ & & & & & 0.86 & & & & 0.90 \\
\hline $\mathrm{Mg}^{2+}$ & & & & 0.55 & 0.76 & & & & 0.91 \\
\hline $\mathrm{Cl}^{-}$ & & & & & 0.76 & & & & 0.90 \\
\hline $\mathrm{Co}$ & & & & & & 0.83 & & & 0.75 \\
\hline $\mathrm{Ni}$ & & & & & 0.59 & 0.70 & & & 0.87 \\
\hline V & & & & & & 0.64 & & & 0.73 \\
\hline $\mathrm{Sr}$ & & & & & & & 0.90 & & 0.84 \\
\hline $\mathrm{Al}$ & & & & & & & 0.89 & & 0.85 \\
\hline $\mathrm{NH}_{4}^{+}$ & & & & & & & & 0.94 & 0.91 \\
\hline $\mathrm{NO}_{3}^{-}$ & & & & & & & & 0.86 & 0.88 \\
\hline
\end{tabular}


Table S2. Source composition results from UNMIX receptor modelling

\begin{tabular}{|c|c|c|c|c|c|c|c|c|c|c|c|c|c|c|c|}
\hline \multirow[b]{3}{*}{ DM10 } & \multicolumn{3}{|c|}{ Industry + traffic } & \multicolumn{3}{|c|}{ Heavy duty vehicles } & \multicolumn{3}{|c|}{ Marine } & \multicolumn{3}{|c|}{ Evaporative emissions } & \multicolumn{3}{|c|}{ Crustal 1} \\
\hline & $\begin{array}{l}\text { Mass } \\
\text { fraction }\end{array}$ & Uncertainty & $\begin{array}{l}\text { Relative } \\
\text { certainty }\end{array}$ & $\begin{array}{l}\text { Mass } \\
\text { fraction }\end{array}$ & Uncertainty & $\begin{array}{l}\text { Relative } \\
\text { certainty }\end{array}$ & $\begin{array}{l}\text { Mass } \\
\text { fraction }\end{array}$ & Uncertainty & $\begin{array}{l}\text { Relative } \\
\text { certainty }\end{array}$ & $\begin{array}{l}\text { Mass } \\
\text { fraction }\end{array}$ & Uncertainty & $\begin{array}{l}\text { Relative } \\
\text { certainty }\end{array}$ & $\begin{array}{l}\text { Mass } \\
\text { fraction }\end{array}$ & Uncertainty & $\begin{array}{l}\text { Relative } \\
\text { certainty }\end{array}$ \\
\hline & 3.178 & 2.744 & 0.6 & 5.450 & 2.832 & 1.0 & 3.685 & 2.168 & 0.8 & -3.262 & 2.977 & -0.5 & 22.966 & 8.041 & 1.4 \\
\hline $\mathrm{Pb}$ & 0.015 & 0.004 & 1.9 & -0.002 & 0.001 & -1.0 & 0.000 & 0.001 & 0.0 & 0.000 & 0.001 & 0.0 & 0.000 & 0.001 & 0.0 \\
\hline $\mathrm{Mn}$ & 0.005 & 0.001 & 2.5 & 0.000 & 0.001 & 0.0 & 0.002 & 0.001 & 1.0 & 0.000 & 0.001 & 0.0 & 0.007 & 0.003 & 1.2 \\
\hline $\mathrm{Fe}$ & 0.153 & 0.047 & 1.6 & 0.013 & 0.043 & 0.2 & 0.088 & 0.044 & 1.0 & 0.033 & 0.052 & 0.3 & 0.319 & 0.128 & 1.2 \\
\hline $\mathrm{Cl}^{-}$ & 0.006 & 0.054 & 0.1 & 0.034 & 0.086 & 0.2 & 0.781 & 0.256 & 1.5 & -0.117 & 0.069 & -0.8 & -0.024 & 0.075 & -0.2 \\
\hline $\mathrm{nmSO}_{4}{ }^{2-}$ & 0.601 & 0.401 & 0.7 & 0.535 & 0.393 & 0.7 & -0.351 & 0.319 & -0.6 & -0.923 & 0.485 & -1.0 & 3.993 & 1.210 & 1.7 \\
\hline $\mathrm{Na}^{+}$ & 0.085 & 0.048 & 0.9 & 0.042 & 0.078 & 0.3 & 0.361 & 0.132 & 1.4 & -0.283 & 0.091 & -1.6 & 0.415 & 0.150 & 1.4 \\
\hline $\mathrm{K}^{+}$ & 0.040 & 0.021 & 1.0 & 0.071 & 0.024 & 1.5 & 0.041 & 0.023 & 0.9 & -0.058 & 0.025 & -1.2 & 0.145 & 0.048 & 1.5 \\
\hline $\mathrm{Mg}^{2+}$ & 0.010 & 0.006 & 0.8 & -0.005 & 0.009 & -0.3 & 0.034 & 0.014 & 1.2 & -0.036 & 0.012 & -1.5 & 0.069 & 0.023 & 1.5 \\
\hline $\mathrm{Ca}^{2+}$ & 0.117 & 0.102 & 0.6 & 0.307 & 0.127 & 1.2 & 0.021 & 0.097 & 0.1 & -0.415 & 0.188 & -1.1 & 1.229 & 0.425 & 1.446 \\
\hline $2+2 / 4 \mathrm{MePhe}$ & 0.000 & 0.000 & & 0.000 & 0.000 & & 0.000 & 0.000 & & 0.001 & 0.000 & & 0.000 & 0.000 & \\
\hline 9MePhe & 0.000 & 0.000 & & 0.000 & 0.000 & & 0.000 & 0.000 & & 0.001 & 0.000 & & 0.000 & 0.000 & \\
\hline 1MePhe & 0.000 & 0.000 & & 0.000 & 0.000 & & 0.000 & 0.000 & & 0.001 & 0.000 & & 0.000 & 0.000 & \\
\hline DiMePhe & 0.000 & 0.000 & & 0.000 & 0.000 & & 0.000 & 0.000 & & 0.001 & 0.000 & & 0.000 & 0.000 & \\
\hline $\mathrm{IP}+\mathrm{DBahA}$ & 0.000 & 0.000 & & 0.002 & 0.000 & & 0.000 & 0.000 & & 0.000 & 0.000 & & -0.001 & 0.000 & \\
\hline BghiPe & 0.000 & 0.000 & & 0.001 & 0.000 & & 0.000 & 0.000 & & 0.000 & 0.000 & & -0.001 & 0.000 & \\
\hline Cor & 0.000 & 0.000 & & 0.002 & 0.001 & & 0.000 & 0.000 & & 0.000 & 0.000 & & -0.001 & 0.000 & \\
\hline
\end{tabular}


Table S3. Pearson correlation coefficients between the common sources identified by the models. All correlation are statistically significant at $99 \%$ level.

\begin{tabular}{|c|c|c|}
\hline Source & Models & Pearson coefficient \\
\hline \multirow[t]{3}{*}{ Crustal 1} & PCA-PMF & 0.85 \\
\hline & PCA-Unmix & 0.82 \\
\hline & PMF-Unmix & 0.75 \\
\hline Crustal 2 & PCA-PMF & 0.94 \\
\hline \multirow[t]{3}{*}{ Marine } & PCA-PMF & 0.73 \\
\hline & PCA-Unmix & 0.79 \\
\hline & PMF-Unmix & 0.69 \\
\hline \multirow[t]{3}{*}{ Industry+traffic } & PCA-PMF & 0.86 \\
\hline & PCA-Unmix & 0.85 \\
\hline & PMF-Unmix & 0.96 \\
\hline \multirow[t]{3}{*}{ Heavy duty vehicles } & $\mathrm{PCA}^{\mathrm{a}}-\mathrm{PMF}$ & 0.74 \\
\hline & $\mathrm{PCA}^{\mathrm{a}}$-Unmix & 0.64 \\
\hline & PMF-Unmix & 0.90 \\
\hline Evaporative emissions & PCA-PMF & 0.92 \\
\hline Biomass combustion & PCA-PMF & 0.90 \\
\hline Fossil fuel combustion & $\mathrm{PCA}^{\mathrm{a}}-\mathrm{PMF}$ & 0.92 \\
\hline
\end{tabular}




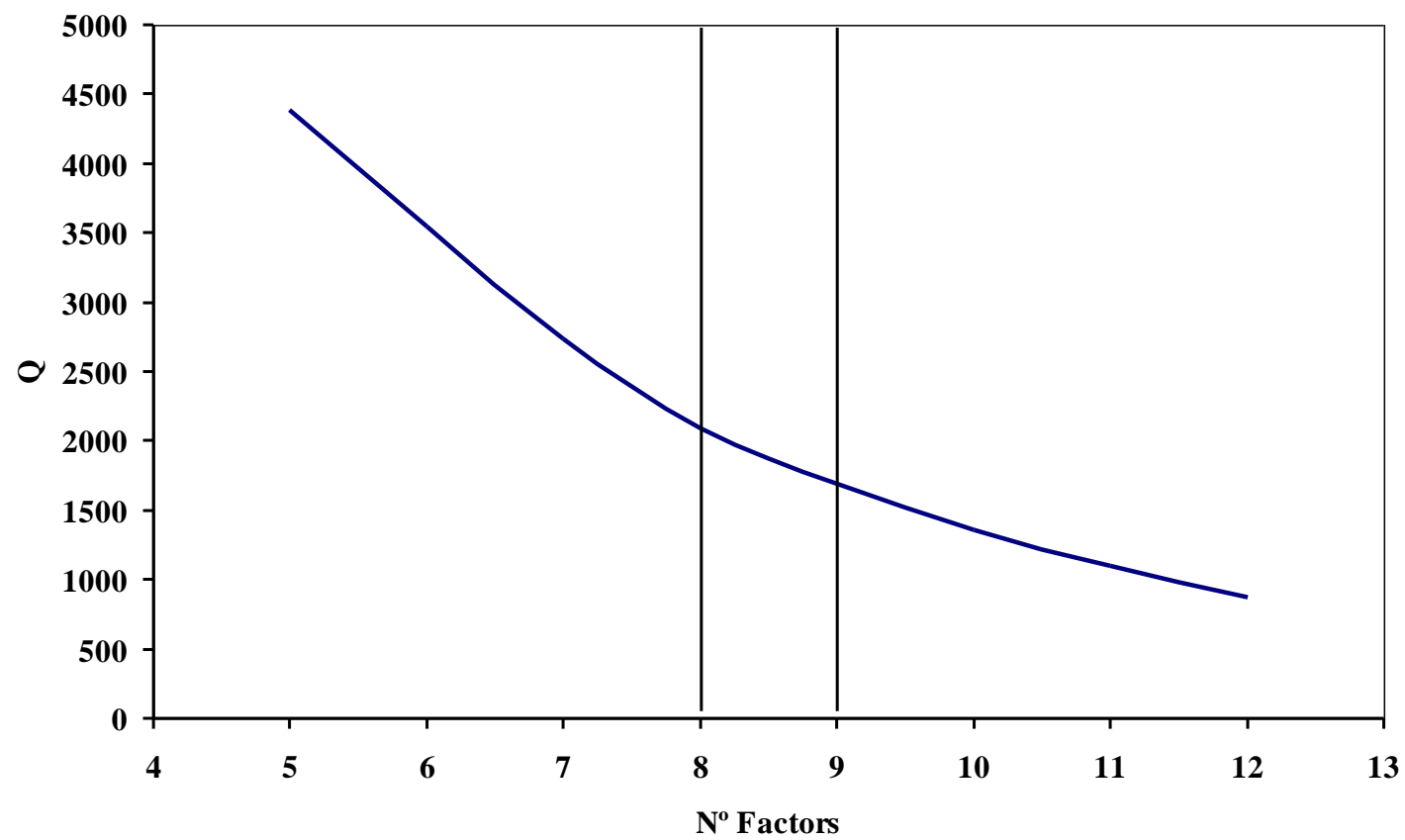

Figure S1. Plot of the Q value as a function of the number of factors in PMF model. 


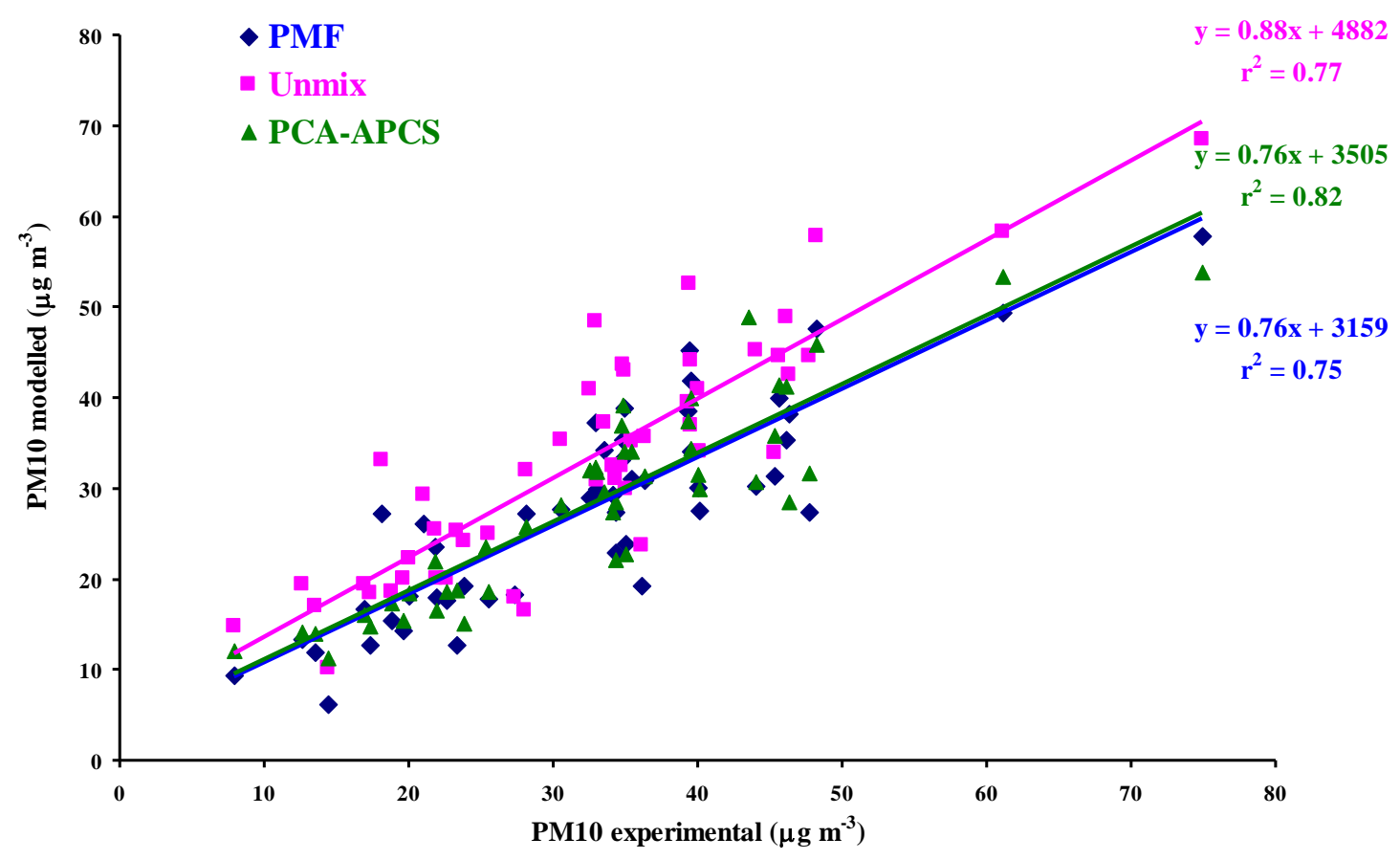

Figure S2. Regressions between measured and modelled PM10 results with the three models: PCA-APCS, Unmix and PMF models (PM10 expressed in $\left.\mu \mathrm{g} \mathrm{m}^{-3}\right)$. 
